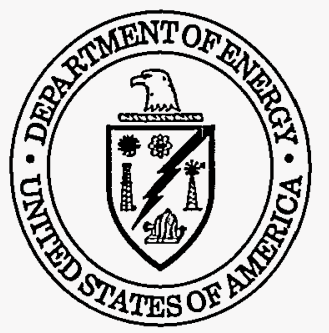

Energy Efficiency and Renewable Energy Federal Energy Management Program

\title{
How to Buy an Energy-Efficient Distribution Transformer
}

\section{Why Agencies Should Buy Efficient Products}

Section 161 of the Energy Policy Act of 1992 (EPACT) encourages energy-efficient federal procurement. Executive Order 12902 and FAR section 23.704 direct agencies to purchase products in the upper $25 \%$ of energy efficiency.

Agencies that use these guidelines to buy efficient products can realize substantial operating cost savings and help prevent pollution.

As the world's largest consumer, the federal government can help "pull" the entire U.S. market towards greater energy efficiency, while saving taxpayer dollars.

\section{Federal Supply Source:}

- Defense Supply Center, Columbus Phone: (614) 692-3236

\section{For More Information:}

- DOE's Federal Energy Management Program (FEMP) Help Desk and World Wide Web site have up-to-date information on energyefficient federal procurement, including the latest versions of these recommendations.

Phone: (800) 363-3732

http://www.eren.doe.gov/femp/procurement

- National Electrical Manufacturers Association (NEMA) publishes "Standard Publication TP-1-1996: Guide for Determining Energy Efficiency for Distribution Transformers."

To order: (800) 854-7179

- Consortium for Energy Efficiency (CEE) provides information on utility programs promoting energy-efficient transformers.

Phone: (617) 589-3949

- Environmental Protection Agency (EPA) will soon have ENERGY STAR $^{\circledR}$ product listings. EPA also provides CITCEM, computer software that performs costeffectiveness analyses for transformers. Phone: (888) 782-7937

http://www.epa.gov/appdstar/transform

- Lawrence Berkeley National Laboratory provided supporting analysis for this recommendation.

Phone: (202) 484-0880

\begin{tabular}{|c|c|c|c|}
\hline \multicolumn{4}{|c|}{ Efficiency Recommendation } \\
\hline \multicolumn{4}{|c|}{ Single Phase Percent Efficiency } \\
\hline \multirow{2}{*}{$\begin{array}{l}\text { Rated } \\
\text { Capacity } \\
\text { (kVA) }\end{array}$} & \multirow{2}{*}{$\begin{array}{c}\text { Low Voltage } \\
\begin{array}{c}\text { Recommended } \\
\text { Leyel }\end{array}\end{array}$} & \multicolumn{2}{|c|}{ Medium Voltage } \\
\hline & & $\begin{array}{c}\text { Recommended } \\
\text { Level (Dry) }\end{array}$ & $\begin{array}{l}\text { Recommended } \\
\text { Level (Liquid) }\end{array}$ \\
\hline 10 & - & - & 98.3 or more \\
\hline 15 & 97.9 or more & 97.6 or more & 98.5 or more \\
\hline 25 & 98.0 ormore & 97.9 ormore & 98.7 or more \\
\hline 37.5 & 98.2 or more & 98.1 or more. & 98.8 or more \\
\hline 50 & 98.3 or more & 98.2 or more & 98.9 or more \\
\hline 75 & 98.5 or more & 98.4 or more & 99.0 or more \\
\hline 100 & 98.6 ormore & 98.5 or more & 99.0 ormore \\
\hline 167 & 98.7 or more & 98.7 or more & 99.1 or more \\
\hline 250 & 98.8 or more & 98.8 or more & 99.2 or more \\
\hline 333 & 98.9 or more & 98.9 or more. & 99.2 or more \\
\hline 500 & - & 99.0 or more & 99.3 or more \\
\hline 667 & - & 99.0 or more & 99.4 or more \\
\hline 833 & - & 99.1 or more & 99.4 or more \\
\hline \multicolumn{4}{|c|}{ Three Phase Percent Efficiency } \\
\hline 15 & 97.0 or more & 96.8 or more & 98.0 ormore \\
\hline 30 & 97.5 or more & 97.3 or more & 98.3 or more \\
\hline 45 & 97.7 or more & 97.6 or mare & 98.5 or more \\
\hline 75 & 98.0 or more & 97.9 or more & 98.7 or more \\
\hline 112.5 & 98.2 or more & g8.1 or more & 98.8 or more \\
\hline 150 & 98.3 or more & 98.2 or more & 98.9 or more \\
\hline 225 & 98.5 or more & 98.4 or more & 99.0 or more \\
\hline 300 & 98.6 ormore & 98.5 or more & 99.0 ormore \\
\hline 500 & 98.7 or more & 98.7 or more & 99.1 or more \\
\hline 750 & 98.8 or more & 98.8 or more & 99.2 or more \\
\hline 1000 & 98.9 or more & 98.9 or more & 99.2 or more \\
\hline 1500 & - & 99.0 or more & 99.3 or more \\
\hline 2000 & - & 99.0 or more & 99.4 or more \\
\hline 2500 & $=$ & 99.1 or more & 99.4 or more \\
\hline
\end{tabular}

Definitions

Energy efficiency of distribution transformers is defined by NEMA's "Standard Publication TP-1" as output $k V A$ divided by the sum of output kVA plus losses, at a specified percent load and reference temperature.

Low voltage transformers have a primary voltage of 1200 volts or less; efficiency is measured at $35 \%$ of nameplate load, at $75^{\circ} \mathrm{C}$.

Medium voltage transformers have a primary voltage greater than 1200 volts; efficiency is measured at $50 \%$ of nameplate load, at $75^{\circ} \mathrm{C}$ for dry-type transformers and $85^{\circ} \mathrm{C}$ for liquid-filled.

Liquid-filled transformers typically use oil as a combination coolant and insulating medium. They are generally higher in efficiency, but are most frequently installed outside.

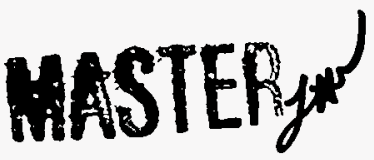


The federal supply source for distribution transformers is the Defense Logistics Agency (DLA)'s Defense Supply Center Columbus (DSCC). Whether you buy from DLA/DSCC or use a commercial supplier or contractor (e.g., an $A \& E$ firm), be sure to specify or select a transformer that meets the Efficiency Recommendation for that capacity and type.

The efficiency levels in this Recommendation are the same as those in NEMA's TP-1 standard (see "For More Information"). Additionally, the EPA/DOE ENERGY STAR program identifies efficient low-voltage distribution transformers with the ENERGY STAR ${ }^{\circledR}$ label. Complying models meet the same efficiency criteria specified in this Recommendation (and TP-1).

Safety codes require that indoor transformer installations meet stringent fire-protection and spill containment conditions. Some "less-flammable liquid-filled" transformers can meet code requirements for indoor uses when applicable fire protection and spill containment conditions are met.

Many types of modern office equipment and devices (personal computers, printers, copiers, fax machines, electronic lighting ballasts) and some industrial equipment (adjustable speed motor drives) impose non-linear loads, which can introduce power wave form distortion. If your transformer serves equipment such as these, consider using a " $\mathrm{K}$ rated" or "drive isolation" transformer designed for specific types of non-linear loads. Simply replacing an existing transformer with a standard unit rated at a higher $k V A$ level is generally not a good approach for these applications. Both first cost and operating cost are frequently higher with larger capacity standard units, which are not designed to accommodate harmonics and other problems imposed by non-linear loads.

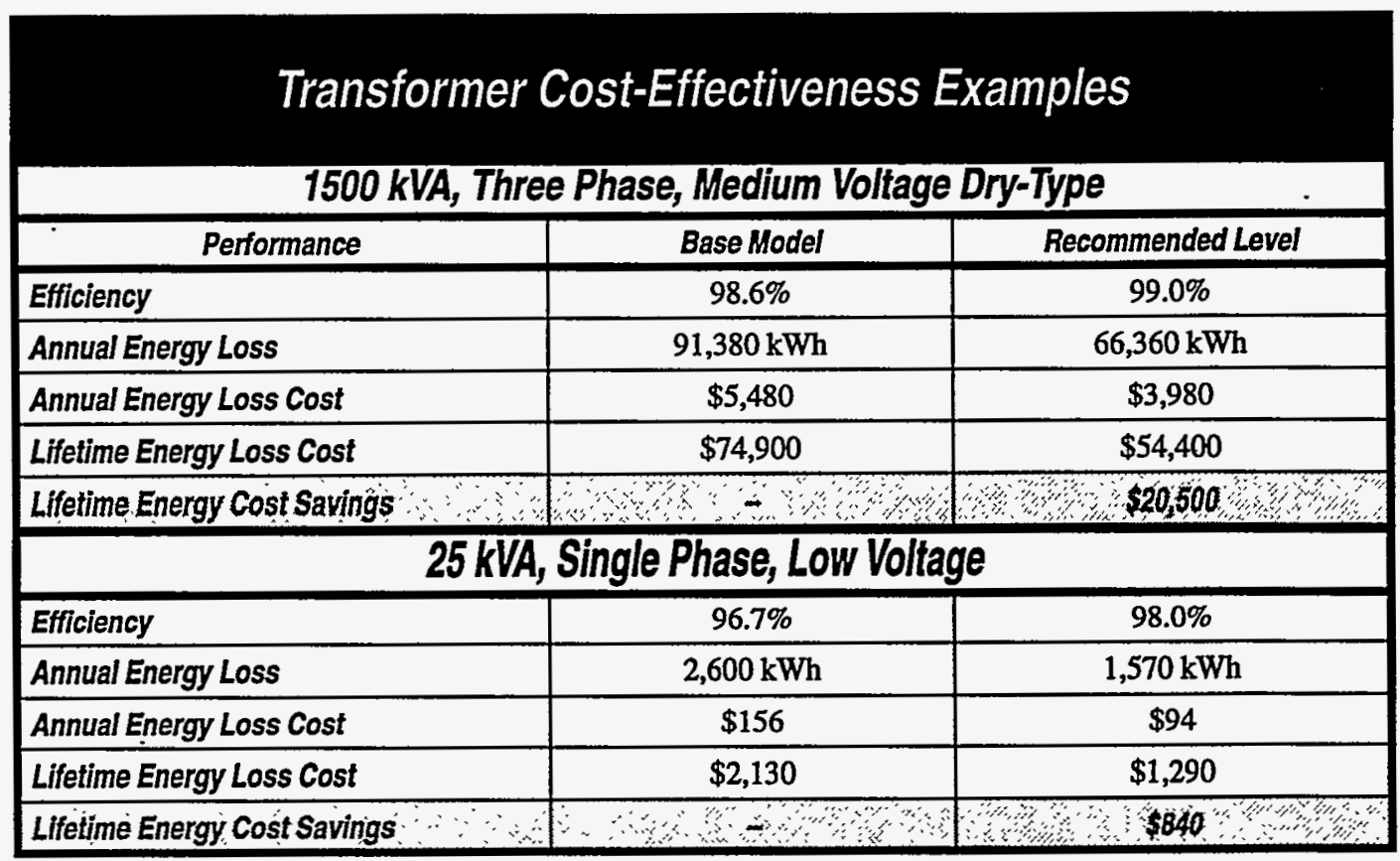

\section{Using the Cost-Effectiveness Table}

In the example shown above, a $1500 \mathrm{kVA}$, three phase, medium voltage transformer at the Recommended efficiency level of $99.0 \%$ is cost-effective if its purchase price is no more than $\$ 20,500$ above the price of the Base Model. Similarly in the $25 \mathrm{kVA}$, single phase, low voltage example, the Recommended model, with an efficiency of $98.0 \%$, is costeffective if its purchase price is no more than $\$ 840$ above the price of the Base Model.

EPA's software analysis program, Commercial and Industrial Transformer Cost Evaluation Model (CITCEM), can assist in evaluating the cost-effectiveness of transformers for both new and replacement applications (see "For More Information").

\section{Where To Find Energy-Efficient Distribution Transformers}

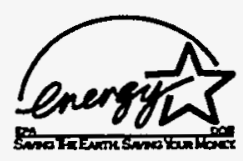

\section{Buyer Tips}

\section{Definitions}

Annual Energy Loss is based on $50 \%$ of nameplate load in the medium voltage example (top), and 35\% of nameplate load in the low voltage example (bottom).

Lifetime Energy Cost Savings is the sum of the discounted value of annual energy cost savings, based on average usage and an assumed transformer life of 25 years. Future electricity price trends and a discount rate of $4.1 \%$ are based on federal guidelines (effective from April, 1998 to March, 1999). The assumed electricity price is $64 / \mathrm{kWh}$, the 1996 federal average electricity price in the U.S. 


\section{DISCLAIMER}

This report was prepared as an account of work sponsored by an agency of the United States Government. Neither the United States Government nor any agency thereof, nor any of their employees, makes any warranty, express or implied, or assumes any legal liability or responsibility for the accuracy, completeness, or usefulness of any information, apparatus, product, or process disclosed, or represents that its use would not infringe privately owned rights. Reference herein to any specific commercial product, process, or service by trade name, trademark, manufacturer, or otherwise does not necessarily constitute or imply its endorsement, recommendation, or favoring by the United States Government or any agency thereof. The views and opinions of authors expressed herein do not necessarily state or reflect those of the United States Government or any agency thereof. 


\section{DISCLAIMER}

Portions of this document may be illegible in electronic image products. Images are produced from the best available original document. 